\title{
Re-inforcing the cell death army in the fight against breast cancer
}

\author{
Clara R. L. Oudenaarden ${ }^{1,2}$, Robert A. H. van de Ven ${ }^{1,3}$ and Patrick W. B. Derksen ${ }^{1, *}$
}

\begin{abstract}
Metastatic breast cancer is responsible for most breast cancer-related deaths. Disseminated cancer cells have developed an intrinsic ability to resist anchorage-dependent apoptosis (anoikis). Anoikis is caused by the absence of cellular adhesion, a process that underpins lumen formation and maintenance during mammary gland development and homeostasis. In healthy cells, anoikis is mostly governed by B-cell lymphoma-2 (BCL2) protein family members. Metastatic cancer cells, however, have often developed autocrine BCL2-dependent resistance mechanisms to counteract anoikis. In this Review, we discuss how a pro-apoptotic subgroup of the BCL2 protein family, known as the BH3-only proteins, controls apoptosis and anoikis during mammary gland homeostasis and to what extent their inhibition confers tumor suppressive functions in metastatic breast cancer. Specifically, the role of the two pro-apoptotic BH3-only proteins BCL2-modifying factor (BMF) and BCL2-interacting mediator of cell death (BIM) will be discussed here. We assess current developments in treatment that focus on mimicking the function of the BH3-only proteins to induce apoptosis, and consider their applicability to restore normal apoptotic responses in anchorageindependent disseminating tumor cells.
\end{abstract}

KEY WORDS: Breast cancer, Intrinsic apoptosis, Metastasis

\section{Introduction}

The mammary gland is one of the few organs that completes its development after birth. Mammary gland development goes through different stages that depend on proper regulation of proliferation and programmed cell death (apoptosis) (Fig. 1A). Sex hormonedependent cyclic organization of growth and survival provides the plasticity of the mammary gland that is needed for its function. Although the mammary gland is not constantly proliferating and branching, it maintains this ability throughout its lifetime. For instance, proliferation, differentiation and invasion before the onset of lactation ensure formation of a functional branched ductal mammary network. At the same time, its apoptotic potential must be repressed until weaning has ceased and involution of the alveoli is induced. In this manner, the developing mammary gland displays many characteristics that are associated with tumor progression, such as invasion, proliferation and resistance to undergoing apoptosis. Hence, failure to maintain a proper balance between cell expansion and cell death is key to the neoplastic growth of mammary tissues.

After embryonic development, selective apoptosis of detached luminal mammary epithelial cells is triggered within the branching mammary ducts that invade into the surrounding fat pad; this

\footnotetext{
1UMC Utrecht, Department of Pathology, Heidelberglaan 100, 3584CX Utrecht, The Netherlands. 'Lund University, Department of Experimental Oncology,

Scheelevägen 2, 22363 Lund, Sweden. ${ }^{3}$ Harvard Medical School, Department of Cell Biology, 250 Longwood Avenue, Boston, MA 02115, USA.

*Author for correspondence (pderksen@umcutrecht.nl)
}

(D) C.R.L.O., 0000-0002-5466-0755; R.A.H.v., 0000-0002-6130-402X; P.W.B.D., 0000-0003-0732-7762 structure is called the terminal end bud (TEB) (Humphreys et al., 1996) (Fig. 1B, top). As a result of the intricate and cyclic interplay of female sex hormones during puberty, the TEB expands into a more elaborate and differentiated branched mammary network that extends to the periphery of the mammary fat pad (Strange et al., 2001; Colitti, 2011; Lanigan et al., 2007). During each estrous cycle, mammary cells undergo phases of proliferation and differentiation that, in the absence of pregnancy, are followed by a regression phase caused by apoptosis of the luminal epithelial cells (Humphreys et al., 1996). When pregnancy is induced, another phase of proliferation and differentiation of alveolar progenitor cells leads to a highly branched lobulo-alveolar network, which sustains milk production (Macias and Hinck, 2012). After lactation and during weaning, a phase of massive apoptotic cell death can be observed in the mammary gland (Medina, 1996; Kumar et al., 2000). This so-called involution allows remodeling of the mammary tree so that its simple architecture is restored and prepared for subsequent pregnancies (Lanigan et al., 2007; Strange et al., 1992). This cyclic organization of proliferation and apoptosis gives the gland the plasticity that is necessary for milk production.

To regulate the delicate balance between proliferation and apoptosis, the postnatal mammary gland is governed by the B-cell lymphoma 2 (BCL2) protein family (Box 1) (hereafter referred to as the BCL2 network) (Medina, 1996; Strange et al., 2001). The BCL2 network consists of both anti- and pro-apoptotic members and has a crucial function in shifting the balance in favor of either an antior pro-apoptotic outcome. Cancerous growth of mammary tissue can take place when mammary epithelial cells fail to produce normal levels of pro- and anti-apoptotic proteins, and an excess of antiapoptotic factors results in repression of apoptosis. Indeed, metastatic breast cancer cells are characterized by an instrinsic resistance against apoptosis (Derksen et al., 2006). Mainly as a result of treatmentresistant metastases, breast cancer still ranks as the fifth deadliest cancer worldwide, despite decreasing mortality rates resulting from early detection, advances in clinical intervention and improved targeted therapies (Autier et al., 2010; Ferlay et al., 2015).

Intrinsic resistance of metastasizing mammary epithelial cells to programmed cell death occurs particularly in the absence of cell attachment (anoikis resistance). Anoikis, from the Greek 'homeless', is defined as apoptosis that is induced upon loss of contact of a cell with its neighboring cells or the extracellular matrix (Frisch and Francis, 1994; Meredith et al., 1993). Proper lumen formation within all glandular epithelial structures is highly dependent on the correct regulation of anoikis (Debnath et al., 2002; Humphreys et al., 1996; Grossmann et al., 2001). To form a functional mammary duct, it is essential that detached luminal epithelial cells undergo BCL2-dependent anoikis (Mailleux et al., 2007; Schmelzle et al., 2007). As stated earlier, resistance to anoikis causes filling of the mammary duct with hyperplastic epithelial cells (Fig. 1C, bottom) and eventually leads to invasive and metastatic breast cancer (Debnath et al., 2002).

Because the BCL2 network controls the development and homeostasis of the mammary gland, it is crucial to identify and 


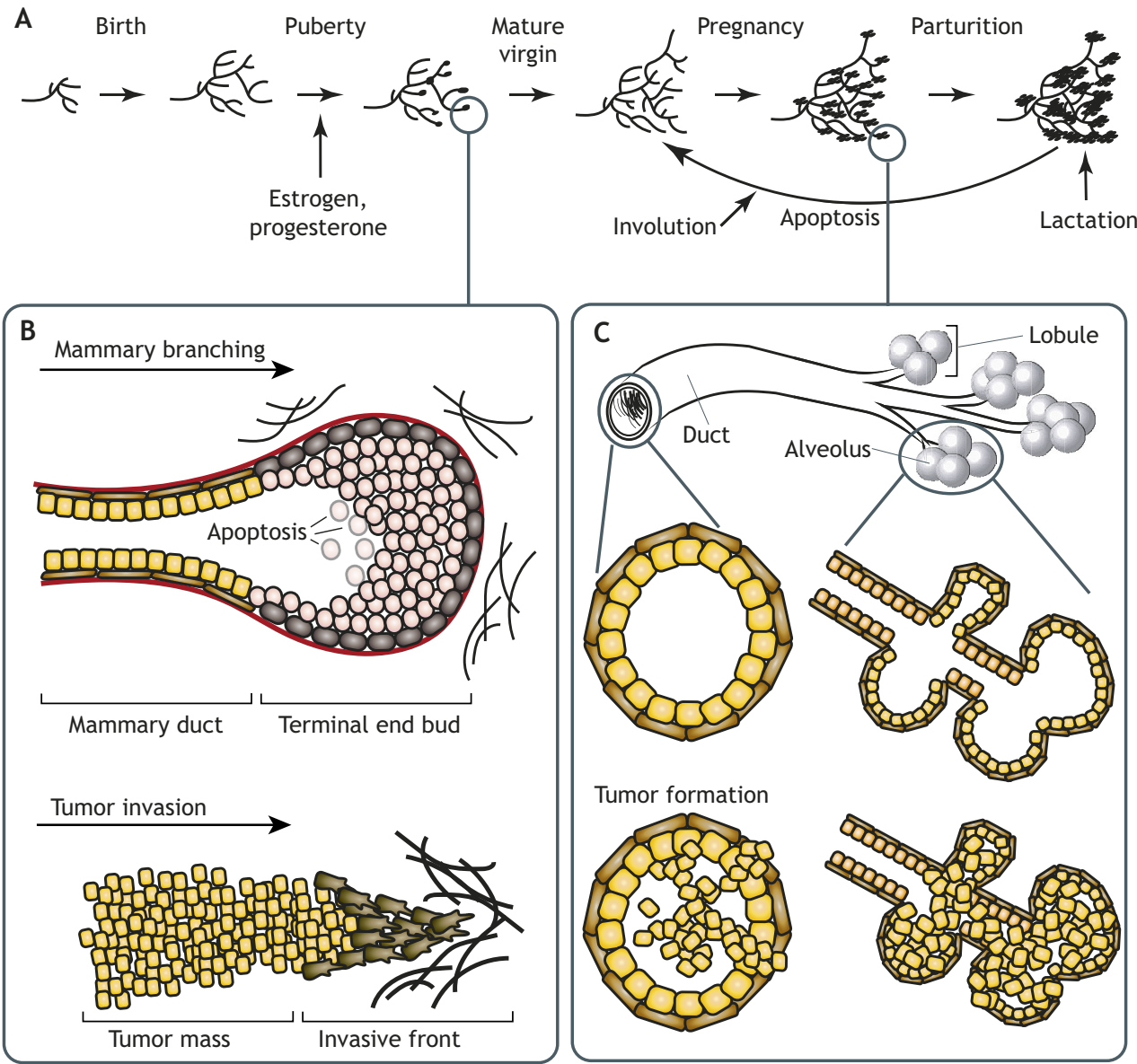

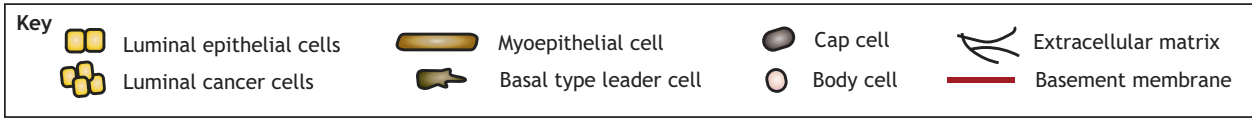

Fig. 1. Mammary gland development. (A) The rudimentary mammary anlage differentiates into a functional gland at the end of puberty. Terminal end buds (TEBs) are developmental structures that underpin mammary branching morphogenesis into the surrounding mammary fat pad. During pregnancy, alveolar development is initiated upon hormonal stimulation; a process that prepares the gland for milk production. Parturition induces active lactation, which is halted after cessation of breast feeding, and leads to mammary tree regression through a process called involution. During involution, apoptosis of many mammary epithelial cells takes places, returning the mammary gland into its ground state. (B) The bulb-shaped terminal buds direct ductal growth into the mammary fat pad. An outer layer of lessdifferentiated cap cells will become myoepithelial cells, and inner located body cells will differentiate into luminal cells or undergo apoptosis in the absence of adherence (anoikis). The basement membrane is thinner at the tip from where the TEB progresses in the surrounding matrix. The invasive character of the front of the TEB can be compared with the invasive front of a tumor mass in the breast. Here, so-called basal type leader cells lead the way of the invasive tumor, degrading the nearby extracellular matrix. (C) Tumor formation in mammary ducts can develop when luminal epithelial cells fail to undergo apoptosis. This results in filling of the mammary ducts, which is characteristic of metastatic breast cancer. investigate the apoptotic factors that underpin the physiology of programmed cell death. This Review focuses on the role of the BCL2 network of programmed cell death and its underlying molecular mechanisms, to better understand their involvement in breast cancer formation and progression. Since cancer cells counterbalance programmed cell death during metastasis, we will also discuss the development of new targeted therapies against the BCL2 network that hold promise for the clinical management of breast cancer.

\section{The BCL2 protein family in breast development}

Proteins of the BCL2 network that are active during mammary gland development control intrinsic apoptosis, which is also known as the mitochondrial apoptotic pathway. This type of apoptosis strongly relies on the balance of activity between pro- and antiapoptotic members of the BCL2 protein family, and differs therein from two other main apoptotic mechanisms, the granzyme B and extrinsic pathways (not further discussed in this Review). The two opposing subfamilies of BCL2 proteins interact with mitochondria, caspases and each other, to regulate apoptosis (Youle and Strasser, 2008). At least fifteen different BCL2 family members have been identified in mammals, which are generally divided into three classes based on their functional and structural characteristics (Box 1) (Fig. 2). A group of anti-apoptotic proteins - BCL2, BCL$\mathrm{x}_{\mathrm{L}}, \mathrm{MCL} 1, \mathrm{BCLW}$ and BCL2A1 - inhibits the oligomerization of two pro-apoptotic proteins (BAX and BAK). All these proteins contain multiple BCL2 homology $(\mathrm{BH})$ domains, in contrast to the third group of BCL2 proteins (BIM, BMF, BID, BAD, BIK, NOXA, PUMA and HRK), which only contain a BH3 domain, and are therefore called the BH3-only proteins (Lomonosova and Chinnadurai, 2008; Aouacheria et al., 2013). In healthy cells, antiapoptotic proteins antagonize the pro-apoptotic function of BAX and $\mathrm{BAK}$ by binding to their $\mathrm{BH} 3$ domains (Box 2). However, in response to intracellular stress signals such as DNA damage, proapoptotic $\mathrm{BH} 3$-only proteins bind and inhibit the anti-apoptotic BCL2 members by inserting their $\mathrm{BH} 3$ domain into the hydrophobic groove of the anti-apoptotic binding partner (Giam et al., 2008; Juin et al., 2013). This interaction induces the release and oligomerization of $\mathrm{BAX}$ and $\mathrm{BAK}$, leading to a release of cytochrome $\mathrm{C}$ from the mitochondrial intermembrane space. Together with other pro-apoptotic constituents such as DIABLO (SMAC), this results in repression of inhibitor of apoptosis proteins (IAPs) (Youle and Strasser, 2008). Subsequently, cytochrome C clusters with apoptotic protease activating factor 1 (APAF1) in the cytoplasm, thereby forming the heptameric apoptosome (Ola et al., 2011). This apoptosome, in turn, leads to the recruitment of procaspase-9 and subsequent activation of caspase-9, which is then able to cleave the effector caspases, caspase-3 and caspase-7, leading to cell death (Fig. 3) (Youle and Strasser, 2008).

The BCL2 protein family members also control anoikis during mammary gland development, specifically through the two proapoptotic BH3-only proteins BCL2-modifying factor (BMF) and BCL2-interacting mediator of cell death (BIM) (Mailleux et al., 2007; 


\section{Box 1. The BCL2 protein family}

The BCL2 family consists of anti- and pro-apoptotic proteins, which contain four different $\mathrm{BCL} 2$ homology $(\mathrm{BH})$ domains named $\mathrm{BH} 1$ to $\mathrm{BH} 4$ that are at most 20 amino acid residues long, with the exception MCL1, which lacks a BH4 domain (Ola et al., 2011; Adams and Cory, 1998). Pro-apoptotic proteins can be divided into two groups, multi-domain proteins and $\mathrm{BH} 3$-only proteins. The former consists of BCL2-associated X-protein (BAX), BCL2 homologous antagonist/killer (BAK) and BCL2 related ovarian killer (BOK), and are structurally very similar to the prosurvival proteins, but only contain BH domains 1 to 3 (Czabotar et al., 2014). There are eight $B H 3$-only proteins: BCL2-interacting mediator of cell death (BIM), BCL2-modifying factor (BMF), BCL2 antagonist of cell death (BAD), BH3-interacting domain death agonist (BID), BCL2interacting killer (BIK), p53 upregulated modulator of apoptosis (PUMA), NOXA (Latin for damage) and hara-kiri (HRK) (Fig. 2) (Lomonosova and Chinnadurai, 2008). Every cell type requires a BCL2 homolog to regulate apoptosis; however, specific pro-apoptotic proteins are essential to evoke apoptosis in different cell types and under different circumstances (Ola et al., 2011). This allows the cells to respond to numerous intracellular death signals. For instance, NOXA and PUMA are subject to transcriptional regulation by $\mathrm{p} 53$ and activated upon DNA damage that is induced by UV radiation (NOXA) and $\gamma$-radiation (PUMA) (Fig. 3) (Youle and Strasser, 2008; Giam et al., 2008). Other means of regulating $B C L 2$ proteins include alternative splicing (e.g. BCL2L1 encodes both the anti-apoptotic long $B C L-x_{L}$ or short $\left.B C L-x_{S}\right)$, posttranslational cleavage (BID to tBID), poly-ubiquitylation (MCL1, BIM) and post-translational phosphorylation (BIM, BAD) (Blume-Jensen et al., 1998; Boise et al., 1993; Li et al., 1998; Zhong et al., 2005; Hübner et al., 2008). Taken together, the BH3-only proteins work as sensors for a variety of cell stresses in the mammalian cell, thereby strictly controlling apoptosis under different circumstances and in different cell types.

\section{Box 2. Structure, binding and selectivity of BCL2 proteins}

Overall, the same secondary and tertiary protein structure is shared by nine of the BCL2 proteins (BCL2, BCL-X $\mathrm{X}_{\mathrm{L}}, \mathrm{BCL}$, MCL1, BCL2A1, BAX, $B A K, B O K$ and $B I D$ ), despite the fact that some of these are pro and others anti-apoptotic (Box 1) (Fig. 2) (Petros et al., 2004; Shamas-Din et al., 2011). These nine proteins all contain a hydrophobic C-terminal domain through which they can anchor to intracellular membranes. In the unbound state, the $\mathrm{C}$-terminus is sequestered in a hydrophobic pocket that is formed by the $\mathrm{BH} 1, \mathrm{BH} 2$ and $\mathrm{BH} 3$ domains (Petros et al., 2004). Through the hydrophobic groove, they can also bind the amphipathic $\alpha$-helix of other BCL2 family members, including the BH3-only proteins (Czabotar et al., 2014; Lomonosova and Chinnadurai, 2008). Remarkably, the short $\mathrm{BH} 3$ domain of 9-16 residues in the $\mathrm{BH} 3$-only proteins exhibits no further structural resemblance to other $\mathrm{BCL} 2$ proteins or each other (Adams and Cory, 1998; Aouacheria et al., 2013).

Small differences in the sequence in the $\mathrm{BH} 3$ domain of the $\mathrm{BH} 3$-only proteins result in a diversity in binding potency and selectivity, thereby allowing them to inhibit different anti-apoptotic BCL2 proteins. For instance, BIM, tBID (truncated BID) and PUMA are more potent apoptosis inducers than the other $\mathrm{BH} 3$-only proteins, as these three $\mathrm{BH} 3-$ only proteins can bind and inhibit all five anti-apoptotic proteins. Conversely, other BH3-only members are only able to bind to a subset of anti-apoptotic proteins. For instance, $B A D$ only interacts with $B C L 2$, $B C L-X_{L}$ and $B C L w$, whereas NOXA binds BCL2A1 and MCL1 (Chen et al., 2005). In this way, the joint action of the 'less-potent' $B H 3$-only proteins BAD and NOXA can still be as effective as BIM or PUMA alone, because in both situations the inhibition of all five anti-apoptotic members is achieved. This selectivity for different anti-apoptotic proteins is due to small structural differences, as substitution of a single amino acid allows $B A D$ to bind all anti-apoptotic proteins, instead of just a subset, rendering it as potent as BIM, tBID, or PUMA (Juin et al., 2013).
Schuler et al., 2016; Schmelzle et al., 2007). Lumen formation during mammary development is partly dependent on the inhibition of antiapoptotic BCL2 proteins by BIM and BMF (Mailleux et al., 2007; Schuler et al., 2016). By gradually shifting from high levels of antiapoptotic proteins during pregnancy and lactation towards that of proapoptotic proteins at the onset of involution, the mammary gland can form a highly branched network that is necessary for lactation and at the same time prepare for a smooth shift to the subsequent apoptotic involution phase (Colitti, 2011; Kumar et al., 2000; Metcalfe et al., 1999; Heermeier et al., 1996).

\section{BH3-only proteins in the mammary gland}

$\mathrm{BIM}$ and $\mathrm{BMF}$ are the two main $\mathrm{BH} 3$-only proteins in mammary development, mostly because of their key role in anoikis and lumen formation. In response to growth factor deprivation or stress in mammary epithelial cells, BIM and BMF are subjected to direct transcriptional activation of the forkhead box transcription factor-3A (FOXO3A) (Dijkers et al., 2000; Hornsveld et al., 2016; Stahl et al., 2002). In particular, the role of BIM in this context has been well investigated. In a situation of cellular contact, activation of mitogen activated protein kinase (MAPK) and AKT by integrin engagement or activation of receptor tyrosine kinases (RTKs) leads to phosphorylation of FOXO3A. Phosphorylation of FOXO3A by MAPK or AKT leads to ubiquitin-mediated degradation of FOXO3A due to binding of MDM2 or 14-3-3, respectively (Brunet et al., 1999; Yang et al., 2008), thereby preventing FOXO3A from transcribing BIM and initiating intrinsic apoptosis (Fig. 3) (Reginato et al., 2005; Dijkers et al., 2000). Additionally, BIM is targeted for ubiquitinmediated degradation by phosphorylation that is mediated by the MAPK extracellular signal-regulated kinase (ERK1/2) (Akiyama et al., 2009). In contrast, upon detachment of mammary epithelial cells, there is a lack of sustained MAPK activity, allowing FOXO3A to translocate to the nucleus and transcribe BIM, thereby triggering controlled cell death (Dijkers et al., 2000).

Since the discovery of BMF as a BH3-only protein it was for a long time unclear if and how transcriptional activation of BMF contributed to anoikis in breast cancer cells. However, a recent study in mouse and human mammary carcinoma cells resolved this issue and found that activation of BMF is also subjected to regulation by integrin engagement and RTK activation (Hornsveld et al., 2016). $\mathrm{BMF}$ was identified as a direct target of $\mathrm{FOXO} 3$ and expression of this BH3-only protein is therefore dependent on inhibition of upstream activation of RTK-dependent signals, such as PI3K-AKT in metastatic breast cancer cells (Hornsveld et al., 2016).

Recent work in mammary gland development suggests another transcriptional regulator for BIM and BMF besides FOXO3A. In cells of the mouse mammary gland it was shown that JAK1regulated activation of transcription factor STAT3 is strongly associated with BMF transcription, and to a lesser extent with transcription of BIM (Sakamoto et al., 2016). STAT3-dependent transcription of BMF and BIM occurred specifically during involution of the mammary gland, a stage of mammary gland development where mammary epithelial cells undergo massive apoptosis (Sakamoto et al., 2016; Watson, 2006).

Besides transcriptional control, BIM is also regulated by alternative splicing and phosphorylation. At least eighteen BIM splicing isoforms have been observed, with the major ones being $\mathrm{BIM}_{\mathrm{EL}}$ (extra long), $\mathrm{BIM}_{\mathrm{L}}$ (long) and $\mathrm{BIM}_{\mathrm{S}}$ (short), of which the latter has the strongest pro-apoptotic activity (Adachi et al., 2005; O'Connor et al., 1998). Depending on the isoform, BIM can either be phosphorylated $\left(\mathrm{BIM}_{\mathrm{EL}}\right)$ or not $\left(\mathrm{BIM}_{\mathrm{S}}\right)$ (Fig. 2) (Ley et al., 2005). Additionally, some isoforms contain a dynein-binding site, whereas others have lost this site during splicing, suggesting that there are distinct roles for different BIM isoforms (Ley et al., 2005). 


$\begin{gathered}\text { Human gene } \\ \text { symbol }\end{gathered}$
$\begin{aligned} & \text { Pnti-apoptotic } \\ & \text { multidomain }\end{aligned}$
$\mathrm{BCL2}$

Pro-apoptotic multidomain

$\begin{array}{ll}\text { BAX (BCL2L4) } & \text { BAX } \\ \text { BAK (BCL2L7) } & \text { BAK } \\ \text { BOK (BCL2L9) } & \text { BOK } \\ \text { BCL2L1 } & \text { BCL- }{ }_{5}\end{array}$

Pro-apoptotic BH3-only

$\begin{array}{ll}\text { BCL2L11 } & \text { BIM } \\ B C L 2 L 11 & \text { BIML } \\ B C L 2 L 11 & \text { BIM }_{S} \\ B M F & \text { BMF } \\ B I D & \text { BID } \\ \text { BAD (BCL2L8) } & \text { BAD } \\ \text { BIK } & \text { BIK } \\ \text { PMAIP1 } & \text { NOXA } \\ B B C 3 & \text { PUMA } \\ \text { HRK } & \text { HRK }\end{array}$
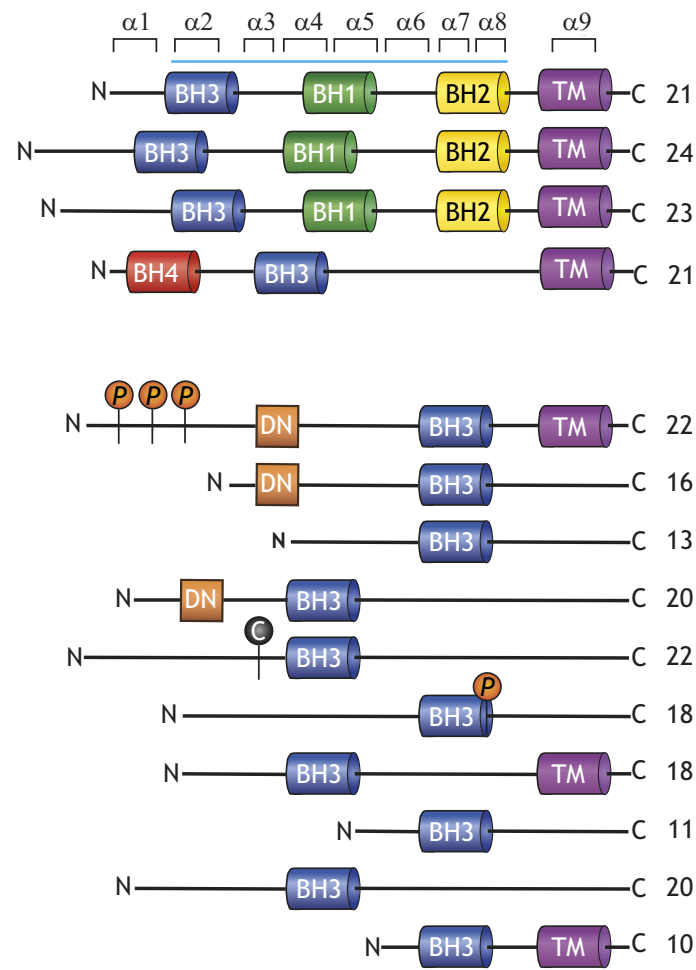

Key

Cleavage site $(P$ Phosphorylation site $\quad$ Hydrophobic groove

Fig. 2. Classification and protein structure of BCL2 family members. Anti-apoptotic BCL2 family members contain all four BCL2 homology (BH) domains, with the exception of MCL1, which only contains $\mathrm{BH} 1$ to $\mathrm{BH}$. The pro-apoptotic multi-domain proteins are structurally similar to the anti-apoptotic members, in that they contain $\mathrm{BH} 1$ to $\mathrm{BH} 3$ domains and a transmembrane domain, except for the $\mathrm{BCL}-\mathrm{x}$ isoform $\mathrm{BCL}-\mathrm{x}_{\mathrm{S}}$. The second pro-apoptotic group contains the $\mathrm{BH} 3-$ only proteins, which only have the $\mathrm{BH} 3$ domain. The $\mathrm{BH}$-only proteins are structurally very diverse and only share homology in the $\mathrm{BH} 3$ domain. The hydrophobic groove of the multi-domain proteins consists of $\alpha$-helices $2-8$, the transmembrane domain consists of $\alpha$-helix 9 . DN, dynein-binding domain; TM, transmembrane domain.

$\mathrm{BIM}_{\mathrm{EL}}$ is subjected to specific phosphorylation-dependent control in human mammary epithelial cells (Reginato et al., 2005). In detached apoptotic luminal mammary cells that eventually undergo anoikis, non-phosphorylated $\mathrm{BIM}_{\mathrm{EL}}$ is present. By contrast, anchored luminal cells that contain phosphorylated $\mathrm{BIM}_{\mathrm{EL}}$ will not undergo anoikis (Reginato et al., 2005). Phosphorylation of $\mathrm{BIM}_{\mathrm{EL}}$ is induced by the active MAPK/ERK signaling cascade, which is widely accepted to be essential for cell survival (Bonni et al., 1999). In addition, the BIM transcription factor FOXO3A is negatively regulated by MAPK-dependent phosphorylation, thereby preventing new BIM mRNA to be transcribed (Yang et al., 2008). This suggests that MAPK/ERK-dependent phosphorylation of $\mathrm{BIM}_{\mathrm{EL}}$ and $\mathrm{FOXO} 3 \mathrm{~A}$, and their subsequent degradation promote cell survival (Luciano et al., 2003). Thus, in attached luminal cells, survival is promoted owing to phosphorylation-dependent repression of $\mathrm{BIM}_{\mathrm{EL}}$ by the MAPK pathway, whereas active unphosphorylated $\mathrm{BIM}_{\mathrm{EL}}$ and transcription of BIM by FOXO3A in the absence of MAPK-mediated phosphorylation leads to anoikis in detached luminal epithelial cells.

\section{BH3-only proteins as tumor suppressors in breast cancer}

Because evasion of apoptosis is considered as a hallmark of cancer (Hanahan and Weinberg, 2000), the pro-apoptotic function of the $\mathrm{BH} 3$-only proteins proposes them as tumor suppressors. Mice knockout for individual BH3-only proteins are viable and develop with relatively few complications, probably due to redundancy among the $\mathrm{BH} 3$-only proteins. However, these mice are more prone to developing hematological malignancies, supporting the 


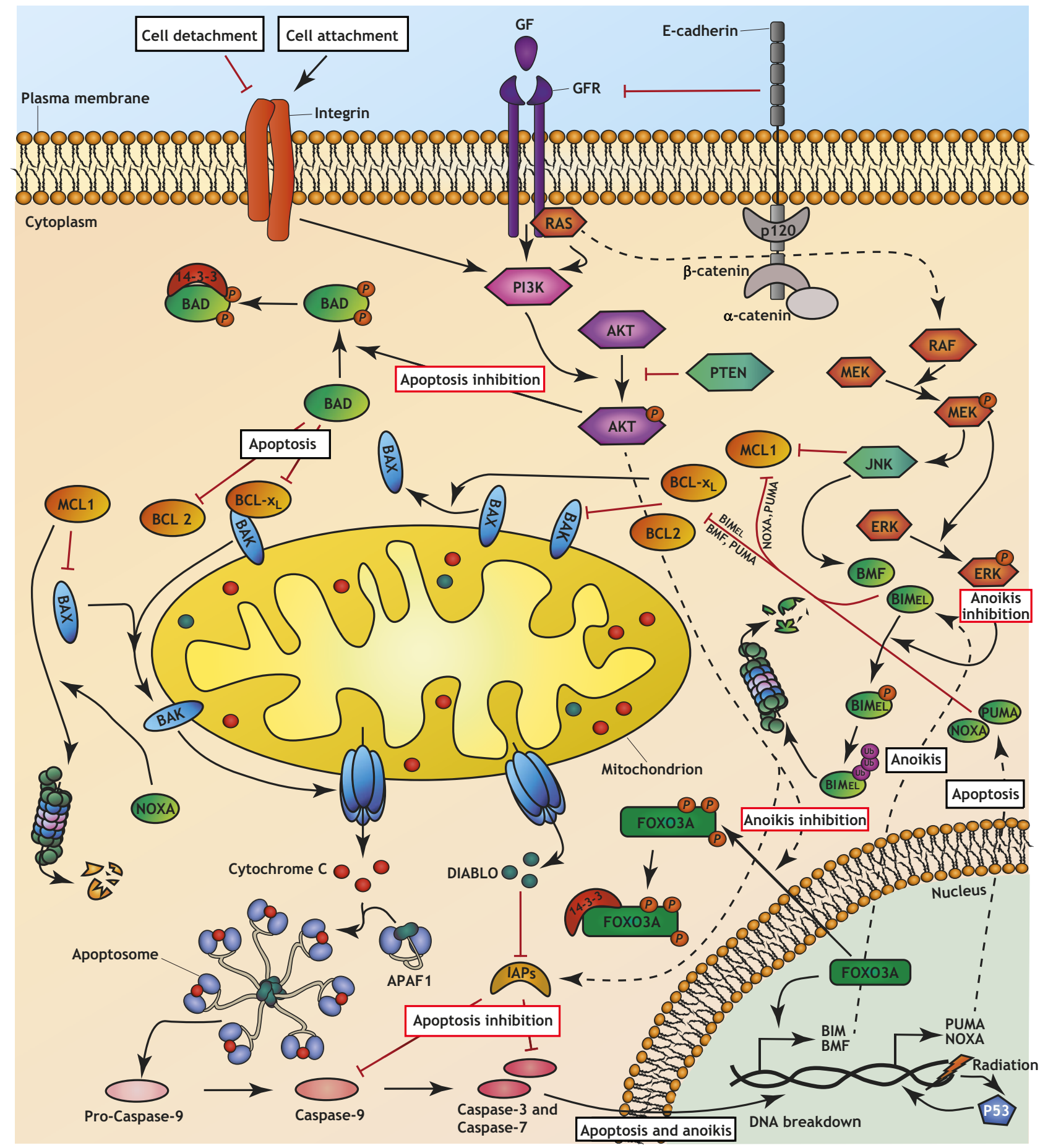

Fig. 3. Apoptotic regulation in mammary epithelial cells. In mammary epithelial cells, extracellular cues, such as growth factors (GFs) and cell attachment are detected by several transmembrane receptors, including integrins, E-cadherin, and growth factor receptors (GFRs), such as HER2. In the presence of growth factors and cellular contact, the PI3K-AKT and MAPK-ERK pathways downstream of these receptors instruct the proteins of the BCL2 network to keep the cell alive (inhibition of apoptosis and anoikis). In this situation, pro-apoptotic BCL2 proteins are inactive: for example, BAD is phosphorylated by AKT and subsequently sequestered by 14-3-3 protein; the transcription factor FOXO3A becomes degraded after ubiquitylation and phosphorylation, and thus BIM and $B M F$ are not transcribed, and BAK and BAX are kept inactive by anti-apoptotic proteins, such as BCL2, BCL- $\mathrm{L}_{\mathrm{L}}$ and $\mathrm{MCL} 1$. In addition, the BH3-only protein $\mathrm{BIM} \mathrm{EL}_{\mathrm{L}}$ is targeted for ubiquitin-mediated proteasomal degradation after ERK-dependent phosphorylation. When cells lose contact with their surroundings (cell detachment), PI3K-AKT and MAPK-ERK signaling is disrupted, allowing expression of the BH3-only proteins BIM, BMF and BAD. Together, these proteins inhibit anti-apoptotic BCL2, BCL- $x_{L}$ and $B C L w$, which results in BAX- or BAK-initiated release of cytochrome $C$ from the mitochondrial intermembrane space.

Subsequently, cytochrome $C$ forms the apoptosome together with APAF1, which then activates caspase-9. This initiator caspase can cleave the downstream effectors caspase- 3 and -7 , which leads to DNA breakdown and apoptotic cell death. The BH3-only proteins BIM $\mathrm{EL}_{\mathrm{L}}$ and BMF are specifically linked to apoptosis after cell detachment (anoikis). Other BH3-only proteins, such as BAD, PUMA, and NOXA, induce apoptosis upon intracellular triggers, such as the radiationtriggered transcription by $\mathrm{p} 53$. 
assumption that the $\mathrm{BH} 3$-only proteins are tumor suppressors (Tuzlak et al., 2016; Youle and Strasser, 2008).

Indeed, BH3-only proteins have a key role in breast cancer development, with a main tumor suppressive role for BIM and BMF in the mammary gland. In the normal mammary ducts, detached luminal epithelial cells undergo BIM- and BMF-mediated anoikis to keep the lumen clear of cells and maintain the ducts for milk secretion. In contrast, in the absence of either one of these proteins, the mammary ducts undergo luminal filling of hyperplastic mammary epithelial cells (Schuler et al., 2016; Mailleux et al., 2007). Luminal filling of the duct with hyperplastic mammary cells is a characteristic of in situ breast cancer, suggesting that the deregulation of the apoptotic machinery may underlie breast cancer development (Bodis et al., 1996). In support of this, it has been shown that knockout of BIM in the MMTV-PyMT mouse model of breast cancer increases metastasis (Merino et al., 2015). Additionally, BMF is located on chromosome $15 \mathrm{q} 14$, which is often lost in metastatic breast cancer (Wick et al., 1996). Furthermore, both BIM and BMF are suppressed during anoikis that is executed under hypoxic conditions (Whelan et al., 2010). Hypoxia, and its main player hypoxia-inducible factor (HIF), are elevated in mammary tumors compared with normal breast tissue (Whelan et al., 2010; Vaupel et al., 2002; Gilkes and Semenza, 2013), suggesting that hypoxia contributes to luminal filling and the disrupted acinar organization that is found in breast carcinoma. A recent study in E-cadherin-deficient and anoikis-resistant mammary cells supports the notion of a tumor suppressive role of BMF in breast cancer (Hornsveld et al., 2016). Here, cells displayed a lack of transcriptional BMF activation specifically when they were grown in the absence of cell attachment. In contrast, E-cadherinexpressing mammary carcinoma cell lines showed a strong increase in the levels of BMF when cultured in the absence of cell adhesion (Hornsveld et al., 2016). Not surprisingly, inducible expression of FOXO3A or BMF was sufficient to inhibit primary tumor outgrowth and metastasis in a transplantation-based mouse model of E-cadherin-deficient breast cancer. In short, these data suggest that there is a therapeutic potential for small molecules resembling BMF to restore anoikis in luminal mammary epithelial cells and prevent breast cancer metastasis (Hornsveld et al., 2016).

\section{Upstream regulators of the BH3-only proteins in breast cancer}

Three receptors are often associated with breast cancer formation and its classification: the human epidermal growth factor receptor 2 (HER2, also known as ERBB2), estrogen receptor (ER) and progesterone receptor (PR) (Hynes, 2000; Daniel et al., 2011). HER2 and other RTKs in breast cancer such as HER1 (also known as epidermal growth factor receptor, EGFR) are essential upstream negative regulators of the $\mathrm{BH} 3$-only proteins and act mainly via three pathways: PI3K-AKT, MAPK-ERK and JNK (Fig. 3) (Reginato et al., 2003; Butti et al., 2018; Carpenter and Lo, 2013). Additionally, loss of the pivotal negative regulator of the AKT pathway, phosphatase and tensin homolog (PTEN), enhances the effect of increased AKT activity and correlates with the aggressiveness of breast tumors (Datta et al., 1999; Ebbesen et al., 2016; Fournier et al., 2009; Bose et al., 2002). Interestingly, conditional PTEN inactivation in the mouse mammary gland impaired apoptosis and increased ductal branching (Li et al., 2002). Mechanistically, downregulation of PTEN releases inhibition of the PI3K-AKT pathway, which affects the expression of the BH3-only proteins in multiple ways (Fig. 3) (Datta et al., 1999). First, AKT stimulates phosphorylation of the $\mathrm{BH} 3$-only protein $\mathrm{BAD}$, which results in its sequestering and inactivation by the 14-3-3 scaffold proteins (Datta et al., 2000; Subramanian et al., 2001). Second, AKT indirectly suppresses BIM and BMF through the phosphorylation and inhibition of their transcription factor FOXO3A (Dijkers et al., 2000; Hornsveld et al., 2016; Brunet et al., 1999). Accordingly, cytosolic localization of FOXOs is associated with poor survival in breast cancer patients (Hu et al., 2004). Finally, even after cytochrome $\mathrm{C}$ release, AKT is able to inhibit apoptosis by direct phosphorylation of caspase-9. This possibly inhibits the catalytic activity of caspase- 9 and blocks the subsequent activation of a cascade of caspases that ultimately cause a controlled breakdown of the cells (Datta et al., 1999). In addition, AKT promotes cell survival by stabilization of IAPs (Fig. 3) and thereby indirectly suppresses the apoptotic cascade following caspase-9 activation (Dan et al., 2004).

The previously discussed MAPK pathway is also activated downstream of HER2 and EGFR. Upon activation of these receptors, this pathway negatively regulates apoptosis, partly because of its inhibition of PTEN (Ebbesen et al., 2016). In membraneanchored cells, RTK signaling results in activated MAPK, which phosphorylates $\mathrm{BIM}_{\mathrm{EL}}$ and thereby induces its ubiquitin-mediated degradation, and subsequently inhibits anoikis (Fig. 3). However, in breast cancer, detached luminal mammary epithelial cells contain phosphorylated $\mathrm{BIM}_{\mathrm{EL}}$, despite disruption of their RTK signaling due to cell detachment, and they therefore resist BIM-mediated anoikis. The resulting luminal filling is characteristic of in situ breast cancer (Colitti, 2012; Reginato et al., 2005).

JNK signaling represents a third pathway downstream of the main hormonal receptors in breast cancer that is involved in anoikis (Martin and Vuori, 2004; Bubici and Papa, 2014). In contrast to MAPK-ERK and PI3K-AKT signaling, JNK can promote, rather than inhibit, anoikis in human mammary epithelial cells, partly through JNK-dependent phosphorylation of BMF (Girnius and Davis, 2017). The tumor suppressive and apoptosis-promoting role of JNK is in line with inactivating mutations found in JNK pathway proteins in human breast cancer and is linked to shortened tumorfree survival in a murine spontaneous breast cancer model (Cellurale et al., 2010; Su et al., 2002).

Therefore, in breast cancer, activation of PI3K-AKT, MAPKERK and JNK converge on the BCL2 network downstream of HER2 and other RTKs, resulting in the direct and indirect inhibition of a wide range of $\mathrm{BH} 3$-only proteins, including BIM and BMF. This emphasizes the importance of the BCL2 and BH3-only proteins in breast cancer and points to the potential for targeted therapies focusing on the BCL2 network.

\section{BH3-only proteins contribute to chemotherapy resistance}

Failure to activate $\mathrm{BH} 3$-only proteins not only enables breast cancer cells to develop tumors, but also underpins cancer progression and chemotherapy resistance. Conventional chemotherapy aims to prevent cancer cell proliferation or induce their apoptosis. However, it appears clear that the intrinsic apoptosis pathway is not properly executed in cancer cells that repress the BH3-only proteins. For instance, the molecular chaperone glucose-related protein $78 \mathrm{kDa}$ (GRP78; also known as HSPA5) is overexpressed in $67 \%$ of malignant breast cancers and confers a slight chemotherapy resistance in breast cancer patients (Fernandez et al., 2000; Lee et al., 2006). GRP78 forms a complex with BH3-only protein BIK in the endoplasmic reticulum, which prevents BIK-induced apoptosis in $\mathrm{ER}^{+}$breast cancer (Fu et al., 2007). Furthermore, mice deficient in BAX show aberrant mammary gland development and accelerated mammary tumor formation (Heermeier et al., 1996; Shibata et al., 
1999). Accordingly, reduced levels of BAX mRNA and protein are observed in breast cancers, and loss of BAX in breast tumors has been correlated with a poor prognosis because these tumors are less responsive to chemotherapy (Bargou et al., 1995; Krajewski et al., 1995).

Additionally, higher levels of anti-apoptotic proteins, such as BCL2 and MCL1, can counteract the pro-apoptotic activity of BH3only proteins. Indeed, upregulation of BCL2 is found in $73 \%$ of breast cancers, with BCL2 overexpression in $85 \%$ of the $\mathrm{ER}^{+}$breast cancer cases, possibly because of the presence of two estrogenresponsive elements in the $B C L 2$ promoter (Vaillant et al., 2013; Dawson et al., 2010). The $M C L 1$ gene is amplified in $20 \%$ of breast cancers (Dawson et al., 2010; Campbell et al., 2018), and high levels of MCL1 have been associated with resistance to the RTK inhibitor lapatinib, which is often used for breast cancer treatment due to its inhibition of HER2 (Martin et al., 2008)

As outlined in these examples and the aforementioned inhibition of BH3-only transcription or release, breast cancer cells deploy both hormone-dependent (BCL2) and -independent means (through MCL1) to circumvent BH3-mediated apoptosis, supporting tumor growth and contributing to chemotherapy resistance. Accordingly, one approach for therapy could be to increase the levels of BH3-only proteins to compensate for the imbalance in levels of anti- and proapoptotic proteins. Indeed, restoring the balance between pro- and antiapoptotic proteins has emerged as a promising strategy to reduce tumor growth and regain chemotherapy sensitivity (Delbridge et al., 2016).

\section{Development of BH3 mimetics}

Over the years, several strategies have been developed in an attempt to shift the balance between the opposing factors of the BCL2 network in cancer in favor of the pro-apoptotic proteins (Strasser et al., 2011). The most promising approach proved to be the use of
BH3 mimetics, owing to their more downstream position in the oncogenic growth factor receptor-dependent pathways. To be recognized as a true $\mathrm{BH} 3$ mimetic, a molecule needs to bind at least one of the BCL2 family members in the nanomolar range and subsequently kill the cell in a BAX-or BAK-dependent manner (Billard, 2013; Lessene et al., 2008). The mechanism of action of a BH3 mimetic comprises the following steps: it disrupts the binding between a native $\mathrm{BH} 3$-only protein and an anti-apoptotic protein, then it replaces the native, captured $\mathrm{BH} 3$-only protein, which leads to the native $\mathrm{BH} 3$ protein being released, so it can consequently exert its function towards BAX and BAK (Fig. 4). In addition, a $\mathrm{BH} 3$ mimetic can also replace BAX or BAK that has been captured by an anti-apoptotic factor (Fig. 4) (Ni Chonghaile and Letai, 2008).

Using innovative library screening techniques together with structural biology, peptide mimetics and advances in combinatorial chemistry, a wide variety of $\mathrm{BH} 3$ mimetics that resemble different BH3-only proteins have been designed (Billard, 2013). Since different $\mathrm{BH} 3$-only proteins exhibit different binding affinities with the anti-apoptotic BCL2 members, it is important to consider which $\mathrm{BH} 3$-only protein a $\mathrm{BH} 3$ mimetic should target (Box 2). Several library screens with naturally occurring products identified bacterial compounds that bind to the hydrophobic groove of BCL2 and BCL- $\mathrm{x}_{\mathrm{L}}$ (Nakashima et al., 2000; Tzung et al., 2001). These endeavors resulted in $\mathrm{BH} 3$ mimetics derived from the cotton plant protein Gossypol, such as its orally available (-)enantiomer AT-101, which binds to anti-apoptotic BCL2, BCL- $\mathrm{x}_{\mathrm{L}}$ and MCL1 (Lessene et al., 2008). AT-101 showed some anti-tumor effects in patients with chronic lymphocytic leukemia (CLL) in phase I/II clinical trials, but appeared less promising in phase II studies for prostate cancer and small cell lung cancer (Ready et al., 2011). Gossypol derivatives were developed in order to reduce the toxic
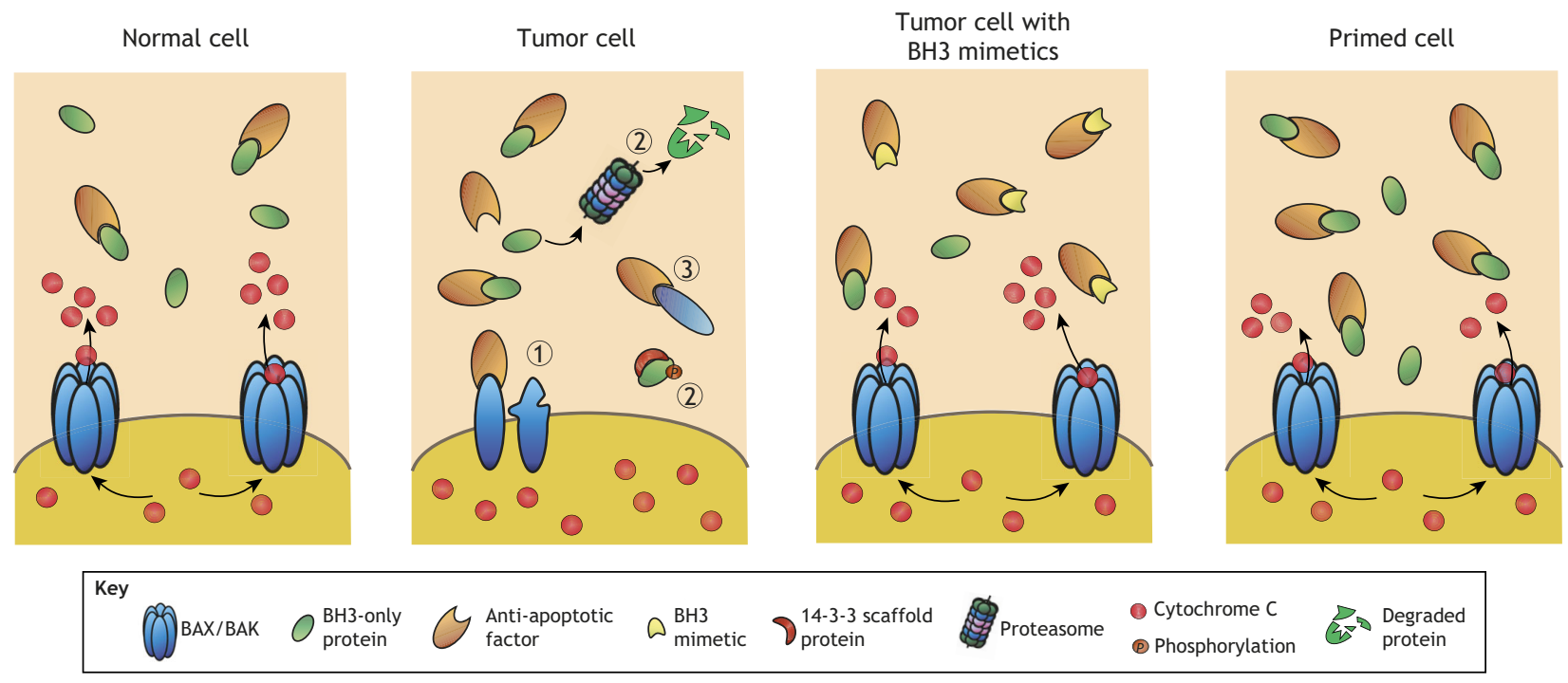

Fig. 4. Mechanism of action of BH3 mimetics. In normal cells under apoptotic conditions, the amount of BH3-only proteins exceeds the amount of anti-apoptotic proteins. This results in free and activated BAX and BAK that can undergo a conformational change and oligomerize in the outer mitochondrial membrane. The latter event induces permeabilisation, release of cytochrome $\mathrm{C}$, and ultimately apoptosis. In tumor cells, multiple mechanisms exist to prevent mitochondrial membrane permeabilisation and subsequent apoptosis. (1) BAX and BAK can be somatically mutated in cancer, leading to attenuation of binding and oligomerization with each other or BH3-only proteins. (2) Levels of BH3-only proteins can be reduced owing to a block in their transcription, proteasome-mediated degradation or sequestration by scaffold proteins when they are phosphorylated. (3) Tumor cells can also have increased levels of anti-apoptotic factors because of a higher transcription rate or enhanced activation. A combination of these mechanisms possibly underpins apoptosis evasion and anoikis resistance in cancer cells. Tumor cells can be treated with small molecules that mimic the $\mathrm{BH} 3$-only proteins. These so-called BH3 mimetics can bind to the hydrophobic groove of antiapoptotic proteins; this compensates for the low levels of $\mathrm{BH}$-only proteins and induces activation of BAX or BAK, release of cytochrome $\mathrm{C}$ and apoptosis. In 'primed' cells, an increased level of anti-apoptotic proteins is compensated by an increased amount of BH3-only proteins. Although anti-apoptotic proteins are abundant, they are captured by $\mathrm{BH} 3$-only proteins. 
effects of Gossypol and to increase its target specificity. These include TW-37, Apogossypolone (ApoG2) and Sabutoclax, which all demonstrate anti-proliferative effects, reduced toxicity and increased serum half-life when compared with Gossypol (Wei et al., 2009; Mohammad et al., 2007; Dash et al., 2011). Although these compounds have shown promising anti-tumorigenic activity in cell lines and mouse models, they have not entered clinical trials so far.

Development of a BH3 mimetic that targets the majority of BCL2 members is of great interest to reduce the chances of acquired resistance for one or several anti-apoptotic members. However, owing to small structural differences between the $\mathrm{BH} 3$ binding groove of MCL1 and the other anti-apoptotic proteins (Box 2), it is challenging to develop a pan-apoptotic BH3 mimetic (Thomas et al., 2013; Lee et al., 2009). Concomitantly, a pan-apoptotic BCL2 inhibitor is more likely to cause toxic effects in healthy cells. Despite these challenges, a non-toxic pan-apoptotic $\mathrm{BH} 3$ mimetic was developed: Obatoclax (GX15-070), which targets BCL2, BCL- $\mathrm{x}_{\mathrm{L}}, \mathrm{BCLw}, \mathrm{MCL} 1$ and BCL2A1 (Goard and Schimmer, 2013; Nguyen et al., 2007). Obatoclax disrupts complex formation between MCL1 and BAK and releases the BH3-only protein BIM from BCL2 (Lessene et al., 2008). Although promising, clinical results were mostly achieved in hematological tumors, which included the complete remission of one acute myeloid leukemia (AML) patient for eight months (Schimmer et al., 2008). Despite the fact that Obatoclax is well tolerated with transient dose-limiting effects such as somnolence, this drug has not been approved for clinical use, mainly because of devastating results in a phase II clinical trial for myelofibrosis, where some patients showed progression in their disease or developed AML and five patients discontinued as a result of adverse side effects (Parikh et al., 2010).

The first rationally designed true $\mathrm{BH} 3$ mimetic ABT-737 was developed with the aid of nuclear magnetic resonance (NMR)-based screening (Oltersdorf et al., 2005). Similar to a wild-type BAD molecule, both ABT-737 and its orally available counterpart ABT263 (Navitoclax) bind with high affinity to anti-apoptotic BCL2, BCLw and BCL- $x_{L}$, but not to MCL1, and result in release of BAX and BAK from BCL2, and BIM from BCL2 (Oakes et al., 2012). Navitoclax is as potent as ABT-737, but exhibits more favorable physiochemical and pharmaceutical properties, making it orally bioavailable (Billard, 2013; Tse et al., 2008). Navitoclax entered early phase clinical trials against several lymphomas, but despite promising anti-tumor effects, studies had to be discontinued due to dosedependent thrombocytopenia (low levels of platelets) at one hour after administration, which occurs because platelets heavily depend on BCL- $\mathrm{x}_{\mathrm{L}}$ for their survival (Oltersdorf et al., 2005; Tse et al., 2008; Wilson et al., 2010). Consequently, this dose-limiting toxicity limits the ability to increase the concentrations of Navitoclax to a range in which they would be highly efficacious. Subsequently, a third true BH3 mimetic was developed to circumvent the toxic effects of Navitoclax. This new compound, ABT-199 (Venetoclax), selectively binds to BCL2 with high affinity, but not to BCL- $\mathrm{x}_{\mathrm{L}}$ or BCLW (Souers et al., 2013). Therefore, Venetoclax has a minimal effect on circulating platelets, resulting in a more effective treatment (Vandenberg and Cory, 2013; Vogler et al., 2013). Venetoclax has proved to be especially valuable in treatment of lymphoma and leukemia, as most of these cancers depend heavily on anti-apoptotic BCL2 (Mihalyova et al., 2018).

\section{BH3 mimetics as targeted intervention strategies to treat breast cancer}

Several putative and true $\mathrm{BH} 3$ mimetics have proved effective in breast cancer therapy, in particular, in combination with conventional chemotherapeutics and ER antagonists. For instance, ABT-737 potentiates the anti-tumor effect of the cytostatic docetaxel in basallike breast cancers that express elevated levels of BCL2 (Oakes et al., 2012). Interestingly, ABT-737 was able to reverse acquired radiotherapy resistance of breast cancer cells (Li et al., 2012). Venetoclax also showed positive results in breast cancer patients, especially in those with an $\mathrm{ER}^{+}$characteristic, as these tumors express high levels of BCL2, which is specifically targeted by Venetoclax (Vaillant et al., 2013; Dawson et al., 2010). Particularly in combination with tamoxifen, Venetoclax significantly decreased tumor growth of breast cancer xenografts (Merino et al., 2015; Vaillant et al., 2013). Moreover, Venetoclax restores anoikis in metastatic E-cadherin-negative mammary carcinoma cells in a dosedependent manner (Hornsveld et al., 2016) and enhances lethality induced by the pan-ERBB inhibitor Neratinib. The latter was hypothesized to occur due to an indirect suppression of MCL1 and BCL- $x_{L}$ and increase of the ATM-AMPK $\alpha-U L K 1(S 317)$ pathway, leading to the formation of toxic autophagosomes (Booth et al., 2018).

Interestingly, the enhanced expression of anti-apoptotic proteins leads not only to drug resistance, as discussed above, but also to drug sensitivity. For instance, expression of the anti-apoptotic BCL2 is commonly associated with a favorable prognosis in breast cancer and exhibits a less-malignant phenotype as compared with patients with a BCL2-negative phenotype (Dawson et al., 2010; Frenzel et al., 2009; Krajewski et al., 1999). This apparent paradox can be explained by the strong induction of the expression of $\mathrm{BH} 3$ only proteins in response to the high levels of BCL2. In a situation where the majority of BCL2 is bound to $\mathrm{BH} 3$-only proteins, the cell could be considered 'primed', and apoptosis will thus occur soon after administration of chemotherapeutics that target the antiapoptotic factor (Fig. 4). However, if the amount of anti-apoptotic proteins exceeds that of the $\mathrm{BH} 3$-only proteins, cells are unprimed and less sensitive for certain types of treatment (Letai, 2008). Therefore, increasing the responsiveness of BH3-only proteins in apoptosis-resistant cells by using $\mathrm{BH} 3$ mimetics may induce a primed state and trigger sensitivity to chemotherapeutic agents. In this way, a combination of using $\mathrm{BH} 3$ mimetics and standard chemotherapy could potentially shift the balance in favor of proapoptotic cancer cell death through BCL2 inhibition, whereas treatment with chemotherapy alone merely returns the cell to its primed state. In short, it is clear that the clinical implementation of BH3 mimetics in combination with standard chemotherapy and/or targeted interventions such as hormone- and growth-factor-receptor antagonists is a promising entrée for the future treatment of metastatic breast cancer.

\section{Conclusions and perspectives}

In conclusion, inhibition of BCL2 survival factors using $\mathrm{BH} 3$ mimetics holds great promise for the treatment of solid cancers that depend on growth factor and/or hormone receptor-dependent attenuation of the intrinsic apoptotic machinery. Current clinical endeavors are focusing on non-small cell lung cancer (SCLC), colon cancer and melanoma, employing the $\mathrm{BH} 3$-only mimetics to augment chemotherapy and targeted intervention regimens. Recent studies have provided a clear rationale for the implementation of Navitoclax and Venetoclax in the management of both ER-positive and ER-negative breast cancer. Because metastatic cancer cells critically depend on anchorage-independent survival, and recent findings have indicated that anoikis resistance of breast cancer cells can be overcome by tilting the pro-apoptotic balance in favor of $\mathrm{BMF}$ and $\mathrm{BIM}$, the time has come to release $\mathrm{BH} 3$-only mimetics into the clinical arena for treatment of invasive breast cancer. 
Competing interests

The authors declare no competing or financial interests.

Funding

This work was supported by grants from The Netherlands Organization for Scientific Research (NWO-VIDI 917.96.318), Dutch Cancer Society grants (KWF-UU-20115230, KWF-UU-2014-7201 and KWF-2017-10456), and the European Union's Horizon 2020 FET Proactive programme under the grant agreement No. 731957 (MECHANO-CONTROL).

\section{References}

Adachi, M., Zhao, X. and Imai, K. (2005). Nomenclature of dynein light chain-linked BH3-only protein Bim isoforms. Cell Death Differ. 12, 192-193.

Adams, J. M. and Cory, S. (1998). The Bcl-2 protein family: arbiters of cell survival. Science 281, 1322-1326.

Akiyama, T., Dass, C. R. and Choong, P. F. (2009). Bim-targeted cancer therapy: a link between drug action and underlying molecular changes. Mol. Cancer Ther. 8 , 3173-3180.

Aouacheria, A., Rech De Laval, V., Combet, C. and Hardwick, J. M. (2013) Evolution of Bcl-2 homology motifs: homology versus homoplasy. Trends Cell Biol. 23, 103-111.

Autier, P., Boniol, M., La Vecchia, C., Vatten, L., Gavin, A., Hery, C. and Heanue, M. (2010). Disparities in breast cancer mortality trends between 30 European countries: retrospective trend analysis of WHO mortality database. BMJ 341 , c3620.

Bargou, R. C., Daniel, P. T., Mapara, M. Y., Bommert, K., Wagener, C., Kallinich, B., Royer, H. D. and Dorken, B. (1995). Expression of the bcl-2 gene family in normal and malignant breast tissue: low bax-alpha expression in tumor cells correlates with resistance towards apoptosis. Int. J. Cancer 60, 854-859.

Billard, C. (2013). BH3 mimetics: status of the field and new developments. Mol. Cancer Ther. 12, 1691-1700.

Blume-Jensen, P., Janknecht, R. and Hunter, T. (1998). The kit receptor promotes cell survival via activation of $\mathrm{PI}$ 3-kinase and subsequent Akt-mediated phosphorylation of Bad on Ser136. Curr. Biol. 8, 779-782

Bodis, S., Siziopikou, K. P., Schnitt, S. J., Harris, J. R. and Fisher, D. E. (1996) Extensive apoptosis in ductal carcinoma in situ of the breast. Cancer 77 . $1831-1835$

Boise, L. H., Gonzalez-Garcia, M., Postema, C. E., Ding, L., Lindsten, T., Turka, L. A., Mao, X., Nunez, G. and Thompson, C. B. (1993). bcl-x, a bcl-2-related gene that functions as a dominant regulator of apoptotic cell death. Cell $\mathbf{7 4}$ 597-608.

Bonni, A., Brunet, A., West, A. E., Datta, S. R., Takasu, M. A. and Greenberg, M. E. (1999). Cell survival promoted by the Ras-MAPK signaling pathway by transcription-dependent and -independent mechanisms. Science 286 1358-1362.

Booth, L., Roberts, J. L., Avogadri-Connors, F., Cutler, R. E., Jr, Lalani, A. S. Poklepovic, A. and Dent, P. (2018). The irreversible ERBB1/2/4 inhibitor neratinib interacts with the BCL-2 inhibitor venetoclax to kill mammary cancer cells. Cancer Biol. Ther. 19, 239-247.

Bose, S., Crane, A., Hibshoosh, H., Mansukhani, M., Sandweis, L. and Parsons, R. (2002). Reduced expression of PTEN correlates with breast cance progression. Hum. Pathol. 33, 405-409.

Brunet, A., Bonni, A., Zigmond, M. J., Lin, M. Z., Juo, P., Hu, L. S., Anderson, M. J., Arden, K. C., Blenis, J. and Greenberg, M. E. (1999). Akt promotes cell survival by phosphorylating and inhibiting a Forkhead transcription factor. Cell $\mathbf{9 6}$, 857-868.

Bubici, C. and Papa, S. (2014). JNK signalling in cancer: in need of new, smarter therapeutic targets. Br. J. Pharmacol. 171, 24-37.

Butti, R., Das, S., Gunasekaran, V. P., Yadav, A. S., Kumar, D. and Kundu, G. C (2018). Receptor tyrosine kinases (RTKs) in breast cancer: signaling, therapeutic implications and challenges. Mol. Cancer 17, 34.

Campbell, K. J., Dhayade, S., Ferrari, N., Sims, A. H., Johnson, E., Mason, S. M., Dickson, A., Ryan, K. M., Kalna, G., Edwards, J. et al. (2018). MCL-1 is a prognostic indicator and drug target in breast cancer. Cell Death Dis. 9, 19.

Carpenter, R. L. and Lo, H. W. (2013). Regulation of apoptosis by HER2 in breast cancer. J. Carcinog. Mutagen. 2013 (Suppl. 7), 3-5

Cellurale, C., Weston, C. R., Reilly, J., Garlick, D. S., Jerry, D. J., Sluss, H. K. and Davis, R. J. (2010). Role of JNK in a Trp53-dependent mouse model of breast cancer. PLoS ONE 5, e12469.

Chen, L., Willis, S. N., Wei, A., Smith, B. J., Fletcher, J. I., Hinds, M. G., Colman, P. M., Day, C. L., Adams, J. M. and Huang, D. C. (2005). Differential targeting of prosurvival $\mathrm{Bcl}-2$ proteins by their $\mathrm{BH} 3$-only ligands allows complementary apoptotic function. Mol. Cell 17, 393-403.

Colitti, M. (2011). Expression of keratin 19, Na-K-Cl cotransporter and estrogen receptor alpha in developing mammary glands of ewes. Histol. Histopathol. 26 1563-1573

Colitti, M. (2012). BCL-2 family of proteins and mammary cellular fate. Anat. Histol. Embryol. 41, 237-247.
Czabotar, P. E., Lessene, G., Strasser, A. and Adams, J. M. (2014). Control of apoptosis by the BCL-2 protein family: implications for physiology and therapy. Nat. Rev. Mol. Cell Biol. 15, 49-63.

Dan, H. C., Sun, M., Kaneko, S., Feldman, R. I., Nicosia, S. V., Wang, H. G., Tsang, B. K. and Cheng, J. Q. (2004). Akt phosphorylation and stabilization of Xlinked inhibitor of apoptosis protein (XIAP). J. Biol. Chem. 279, 5405-5412.

Daniel, A. R., Hagan, C. R. and Lange, C. A. (2011). Progesterone receptor action: defining a role in breast cancer. Expert. Rev. Endocrinol. Metab. 6, 359-369.

Dash, R., Azab, B., Quinn, B. A., Shen, X., Wang, X.-Y., Das, S. K., Rahmani, M. Wei, J., Hedvat, M., Dent, P. et al. (2011). Apogossypol derivative BI-97C1 (Sabutoclax) targeting Mcl-1 sensitizes prostate cancer cells to mda-7/IL-24mediated toxicity. Proc. Natl. Acad. Sci. USA 108, 8785-8790.

Datta, S. R., Brunet, A. and Greenberg, M. E. (1999). Cellular survival: a play in three Akts. Genes Dev. 13, 2905-2927.

Datta, S. R., Katsov, A., Hu, L., Petros, A., Fesik, S. W., Yaffe, M. B. and Greenberg, M. E. (2000). 14-3-3 proteins and survival kinases cooperate to inactivate $\mathrm{BAD}$ by $\mathrm{BH} 3$ domain phosphorylation. Mol. Cell 6, 41-51.

Dawson, S. J., Makretsov, N., Blows, F. M., Driver, K. E., Provenzano, E., Le Quesne, J., Baglietto, L., Severi, G., Giles, G. G., Mclean, C. A. et al. (2010) BCL2 in breast cancer: a favourable prognostic marker across molecular subtypes and independent of adjuvant therapy received. Br. J. Cancer 103, 668-675.

Debnath, J., Mills, K. R., Collins, N. L., Reginato, M. J., Muthuswamy, S. K. and Brugge, J. S. (2002). The role of apoptosis in creating and maintaining luminal space within normal and oncogene-expressing mammary acini. Cell 111, 29-40. Delbridge, A. R., Grabow, S., Strasser, A. and Vaux, D. L. (2016). Thirty years of BCL-2: translating cell death discoveries into novel cancer therapies. Nat. Rev. Cancer 16, 99-109.

Derksen, P. W., Liu, X., Saridin, F., Van Der Gulden, H., Zevenhoven, J., Evers, B., Van Beijnum, J. R., Griffioen, A. W., Vink, J., Krimpenfort, P. et al. (2006) Somatic inactivation of E-cadherin and p53 in mice leads to metastatic lobula mammary carcinoma through induction of anoikis resistance and angiogenesis. Cancer Cell 10, 437-449.

Dijkers, P. F., Medema, R. H., Lammers, J. W., Koenderman, L. and Coffer, P. J. (2000). Expression of the pro-apoptotic Bcl-2 family member Bim is regulated by the forkhead transcription factor FKHR-L1. Curr. Biol. 10, 1201-1204.

Ebbesen, S. H., Scaltriti, M., Bialucha, C. U., Morse, N., Kastenhuber, E. R. Wen, H. Y., Dow, L. E., Baselga, J. and Lowe, S. W. (2016). Pten loss promotes MAPK pathway dependency in HER2/neu breast carcinomas. Proc. Natl. Acad. Sci. USA 113, 3030-3035.

Ferlay, J., Soerjomataram, I., Dikshit, R., Eser, S., Mathers, C., Rebelo, M. Parkin, D. M., Forman, D. and Bray, F. (2015). Cancer incidence and mortality worldwide: sources, methods and major patterns in GLOBOCAN 2012 Int. J. Cancer 136, E359-E386.

Fernandez, P. M., Tabbara, S. O., Jacobs, L. K., Manning, F. C., Tsangaris, T. N. Schwartz, A. M., Kennedy, K. A. and Patierno, S. R. (2000). Overexpression of the glucose-regulated stress gene GRP78 in malignant but not benign human breast lesions. Breast Cancer Res. Treat. 59, 15-26.

Fournier, M. V., Fata, J. E., Martin, K. J., Yaswen, P. and Bissell, M. J. (2009) Interaction of E-cadherin and PTEN regulates morphogenesis and growth arrest in human mammary epithelial cells. Cancer Res. 69, 4545-4552.

Frenzel, A., Grespi, F., Chmelewskij, W. and Villunger, A. (2009). Bcl2 family proteins in carcinogenesis and the treatment of cancer. Apoptosis 14, 584-596.

Frisch, S. M. and Francis, H. (1994). Disruption of epithelial cell-matrix interactions induces apoptosis. J. Cell Biol. 124, 619-626

Fu, Y., Li, J. and Lee, A. S. (2007). GRP78/BiP inhibits endoplasmic reticulum BIK and protects human breast cancer cells against estrogen starvation-induced apoptosis. Cancer Res. 67, 3734-3740.

Giam, M., Huang, D. C. and Bouillet, P. (2008). BH3-only proteins and their roles in programmed cell death. Oncogene 27 Suppl. 1, S128-S136.

Gilkes, D. M. and Semenza, G. L. (2013). Role of hypoxia-inducible factors in breast cancer metastasis. Future Oncol. 9, 1623-1636.

Girnius, N. and Davis, R. J. (2017). JNK promotes epithelial cell anoikis by transcriptional and post-translational regulation of $\mathrm{BH} 3-$ only proteins. Cell Rep. 21, 1910-1921.

Goard, C. A. and Schimmer, A. D. (2013). An evidence-based review of obatoclax mesylate in the treatment of hematological malignancies. Core Evid. 8, 15-26.

Grossmann, J., Walther, K., Artinger, M., Kiessling, S. and Scholmerich, J. (2001). Apoptotic signaling during initiation of detachment-induced apoptosis ("anoikis") of primary human intestinal epithelial cells. Cell Growth Differ. 12 147-155.

Hanahan, D. and Weinberg, R. A. (2000). The hallmarks of cancer. Cell 100, 57-70 Heermeier, K., Benedict, M., Li, M., Furth, P., Nuñez, G. and Hennighausen, L. (1996). Bax and Bcl-xs are induced at the onset of apoptosis in involuting mammary epithelial cells. Mech. Dev. 56, 197-207.

Hornsveld, M., Tenhagen, M., van de Ven, R. A., Smits, A. M. M., van Triest, M. H., van Amersfoort, M., Kloet, D. E., Dansen, T. B., Burgering, B. M. and Derksen, P. W. (2016). Restraining FOXO3-dependent transcriptional BMF activation underpins tumour growth and metastasis of E-cadherin-negative breas cancer. Cell Death Differ. 23, 1483-1492. 
Hu, M. C.-T., Lee, D.-F., Xia, W., Golfman, L. S., Ou-Yang, F., Yang, J.-Y., Zou, Y., Bao, S., Hanada, N., Saso, H. et al. (2004). IkappaB kinase promotes tumorigenesis through inhibition of forkhead FOXO3a. Cell 117, 225-237.

Hübner, A., Barrett, T., Flavell, R. A. and Davis, R. J. (2008). Multi-site phosphorylation regulates bim stability and apoptotic activity. Mol. Cell 30, 415-425.

Humphreys, R. C., Krajewska, M., Krnacik, S., Jaeger, R., Weiher, H., Krajewski, S., Reed, J. C. and Rosen, J. M. (1996). Apoptosis in the terminal endbud of the murine mammary gland: a mechanism of ductal morphogenesis. Development 122, 4013-4022.

Hynes, N. E. (2000). Tyrosine kinase signalling in breast cancer. Breast Cancer Res. 2, 154-157.

Juin, P., Geneste, O., Gautier, F., Depil, S. and Campone, M. (2013). Decoding and unlocking the BCL-2 dependency of cancer cells. Nat. Rev. Cancer 13, 455-465

Krajewski, S., Blomqvist, C., Franssila, K., Krajewska, M., Wasenius, V. M. Niskanen, E., Nordling, S. and Reed, J. C. (1995). Reduced expression of proapoptotic gene BAX is associated with poor response rates to combination chemotherapy and shorter survival in women with metastatic breast adenocarcinoma. Cancer Res. 55, 4471-4478.

Krajewski, S., Krajewska, M., Turner, B. C., Pratt, C., Howard, B., Zapata, J. M. Frenkel, V., Robertson, S., Ionov, Y., Yamamoto, H. et al. (1999). Prognostic significance of apoptosis regulators in breast cancer. Endocr Relat. Cancer 6 29-40.

Kumar, R., Vadlamudi, R. K. and Adam, L. (2000). Apoptosis in mammary gland and cancer. Endocr Relat. Cancer 7, 257-269.

Lanigan, F., O'connor, D., Martin, F. and Gallagher, W. M. (2007). Molecular links between mammary gland development and breast cancer. Cell. Mol. Life Sci. 64 , 3159-3184

Lee, E., Nichols, P., Spicer, D., Groshen, S., Yu, M. C. and Lee, A. S. (2006) GRP78 as a novel predictor of responsiveness to chemotherapy in breast cancer. Cancer Res. 66, 7849-7853.

Lee, E. F., Czabotar, P. E., Yang, H., Sleebs, B. E., Lessene, G., Colman, P. M., Smith, B. J. and Fairlie, W. D. (2009). Conformational changes in Bcl-2 prosurvival proteins determine their capacity to bind ligands. J. Biol. Chem. 284 30508-30517.

Lessene, G., Czabotar, P. E. and Colman, P. M. (2008). BCL-2 family antagonists for cancer therapy. Nat. Rev. Drug Discov. 7, 989-1000.

Letai, A. G. (2008). Diagnosing and exploiting cancer's addiction to blocks in apoptosis. Nat. Rev. Cancer 8, 121-132.

Ley, R., Ewings, K. E., Hadfield, K. and Cook, S. J. (2005). Regulatory phosphorylation of Bim: sorting out the ERK from the JNK. Cell Death Differ 12, 1008-1014

Li, H., Zhu, H., Xu, C. J. and Yuan, J. (1998). Cleavage of BID by caspase 8 mediates the mitochondrial damage in the Fas pathway of apoptosis. Cell 94 491-501.

Li, G., Robinson, G. W., Lesche, R., Martinez-Diaz, H., Jiang, Z., Rozengurt, N., Wagner, K. U., Wu, D. C., Lane, T. F., Liu, X. et al. (2002). Conditional loss of PTEN leads to precocious development and neoplasia in the mammary gland. Development 129, 4159-4170.

Li, J.-Y., Li, Y.-Y., Jin, W., Yang, Q., Shao, Z.-M. and Tian, X.-S. (2012). ABT-737 reverses the acquired radioresistance of breast cancer cells by targeting $\mathrm{Bcl}-2$ and Bcl-xL. J. Exp. Clin. Cancer Res. 31, 102.

Lomonosova, E. and Chinnadurai, G. (2008). BH3-only proteins in apoptosis and beyond: an overview. Oncogene 27 Suppl. 1, S2-S19.

Luciano, F., Jacquel, A., Colosetti, P., Herrant, M., Cagnol, S., Pages, G. and Auberger, P. (2003). Phosphorylation of Bim-EL by Erk1/2 on serine 69 promotes its degradation via the proteasome pathway and regulates its proapoptotic function. Oncogene 22, 6785-6793.

Macias, H. and Hinck, L. (2012). Mammary gland development. Wiley Interdiscip Rev. Dev. Biol. 1, 533-557.

Mailleux, A. A., Overholtzer, M., Schmelzle, T., Bouillet, P., Strasser, A. and Brugge, J. S. (2007). BIM regulates apoptosis during mammary ductal morphogenesis, and its absence reveals alternative cell death mechanisms. Dev. Cell 12, 221-234.

Martin, S. S. and Vuori, K. (2004). Regulation of Bcl-2 proteins during anoikis and amorphosis. Biochim. Biophys. Acta 1692, 145-157.

Martin, A. P., Miller, A., Emad, L., Rahmani, M., Walker, T., Mitchell, C., Hagan, M. P., Park, M. A., Yacoub, A., Fisher, P. B. et al. (2008). Lapatinib resistance in HCT116 cells is mediated by elevated MCL-1 expression and decreased BAK activation and not by ERBB receptor kinase mutation. Mol. Pharmacol. 74, 807-822.

Medina, D. (1996). The mammary gland: a unique organ for the study of development and tumorigenesis. J. Mammary Gland Biol. Neoplasia 1, 5-19.

Meredith, J. E., Jr, Fazeli, B. and Schwartz, M. A. (1993). The extracellular matrix as a cell survival factor. Mol. Biol. Cell 4, 953-961.

Merino, D., Best, S. A., Asselin-Labat, M.-L., Vaillant, F., Pal, B., Dickins, R. A. Anderson, R. L., Strasser, A., Bouillet, P., Lindeman, G. J. et al. (2015). Proapoptotic Bim suppresses breast tumor cell metastasis and is a target gene of SNAI2. Oncogene 34, 3926-3934.
Metcalfe, A. D., Gilmore, A., Klinowska, T., Oliver, J., Valentijn, A. J., Brown, R., Ross, A., Macgregor, G., Hickman, J. A. and Streuli, C. H. (1999) Developmental regulation of Bcl-2 family protein expression in the involuting mammary gland. J. Cell Sci. 112, 1771-1783.

Mihalyova, J., Jelinek, T., Growkova, K., Hrdinka, M., Simicek, M. and Hajek, R. (2018). Venetoclax: a new wave in hematooncology. Exp. Hematol. 61, 10-25.

Mohammad, R. M., Goustin, A. S., Aboukameel, A., Chen, B., Banerjee, S. Wang, G., Nikolovska-Coleska, Z., Wang, S. and Al-Katib, A. (2007) Preclinical studies of TW-37, a new nonpeptidic small-molecule inhibitor of Bcl2 , in diffuse large cell lymphoma xenograft model reveal drug action on both $\mathrm{Bcl}-2$ and Mcl-1. Clin. Cancer Res. 13, 2226-2235

Nakashima, T., Miura, M. and Hara, M. (2000). Tetrocarcin A inhibits mitochondrial functions of Bcl-2 and suppresses its anti-apoptotic activity. Cancer Res. 60, 1229-1235.

Nguyen, M., Marcellus, R. C., Roulston, A., Watson, M., Serfass, L., Murthy Madiraju, S. R., Goulet, D., Viallet, J., Belec, L., Billot, X. et al. (2007). Smal molecule obatoclax (GX15-070) antagonizes MCL-1 and overcomes MCL-1 mediated resistance to apoptosis. Proc. Natl. Acad. Sci. USA 104, 19512-19517. Ni Chonghaile, T. and Letai, A. (2008). Mimicking the BH3 domain to kill cancer cells. Oncogene 27 Suppl. 1, S149-S157.

Oakes, S. R., Vaillant, F., Lim, E., Lee, L., Breslin, K., Feleppa, F., Deb, S. Ritchie, M. E., Takano, E., Ward, T. et al. (2012). Sensitization of BCL-2 expressing breast tumors to chemotherapy by the BH3 mimetic ABT-737. Proc. Natl. Acad. Sci. USA 109, 2766-2771.

O'connor, L., Strasser, A., O'reilly, L. A., Hausmann, G., Adams, J. M., Cory, S. and Huang, D. C. (1998). Bim: a novel member of the Bcl-2 family that promotes apoptosis. EMBO J. 17, 384-395.

Ola, M. S., Nawaz, M. and Ahsan, H. (2011). Role of Bcl-2 family proteins and caspases in the regulation of apoptosis. Mol. Cell. Biochem. 351, 41-58.

Oltersdorf, T., Elmore, S. W., Shoemaker, A. R., Armstrong, R. C., Augeri, D. J., Belli, B. A., Bruncko, M., Deckwerth, T. L., Dinges, J., Hajduk, P. J. et al. (2005). An inhibitor of $\mathrm{Bcl}-2$ family proteins induces regression of solid tumours Nature 435, 677-681.

Parikh, S. A., Kantarjian, H., Schimmer, A., Walsh, W., Asatiani, E., El-Shami, K., Winton, E. and Verstovsek, S. (2010). Phase II study of obatoclax mesylate (GX15-070), a small-molecule BCL-2 family antagonist, for patients with myelofibrosis. Clin. Lymphoma. Myeloma. Leuk. 10, 285-289.

Petros, A. M., Olejniczak, E. T. and Fesik, S. W. (2004). Structural biology of the Bcl-2 family of proteins. Biochim. Biophys. Acta 1644, 83-94.

Ready, N., Karaseva, N. A., Orlov, S. V., Luft, A. V., Popovych, O., Holmlund, J. T., Wood, B. A. and Leopold, L. (2011). Double-blind, placebo-controlled, randomized phase 2 study of the proapoptotic agent AT-101 plus docetaxel, in second-line non-small cell lung cancer. J. Thorac. Oncol. 6, 781-785

Reginato, M. J., Mills, K. R., Paulus, J. K., Lynch, D. K., Sgroi, D. C., Debnath, J., Muthuswamy, S. K. and Brugge, J. S. (2003). Integrins and EGFR coordinately regulate the pro-apoptotic protein Bim to prevent anoikis. Nat. Cell Biol. 5 733-740.

Reginato, M. J., Mills, K. R., Becker, E. B. E., Lynch, D. K., Bonni, A., Muthuswamy, S. K. and Brugge, J. S. (2005). Bim regulation of lumen formation in cultured mammary epithelial acini is targeted by oncogenes. Mol. Cell. Biol. 25 4591-4601.

Sakamoto, K., Wehde, B. L., Yoo, K. H., Kim, T., Rajbhandari, N., Shin, H. Y., Triplett, A. A., Rädler, P. D., Schuler, F., Villunger, A. et al. (2016). Janus Kinase 1 Is Essential for Inflammatory Cytokine Signaling and Mammary Gland Remodeling. Mol. Cell. Biol. 36, 1673-1690.

Schimmer, A. D., O’brien, S., Kantarjian, H., Brandwein, J., Cheson, B. D., Minden, M. D., Yee, K., Ravandi, F., Giles, F., Schuh, A. et al. (2008). A phase study of the pan bcl-2 family inhibitor obatoclax mesylate in patients with advanced hematologic malignancies. Clin. Cancer Res. 14, 8295-8301.

Schmelzle, T., Mailleux, A. A., Overholtzer, M., Carroll, J. S., Solimini, N. L. Lightcap, E. S., Veiby, O. P. and Brugge, J. S. (2007). Functional role and oncogene-regulated expression of the $\mathrm{BH}$-only factor Bmf in mammary epithelia anoikis and morphogenesis. Proc. Natl. Acad. Sci. USA 104, 3787-3792.

Schuler, F., Baumgartner, F., Klepsch, V., Chamson, M., Müller-Holzner, E., Watson, C. J., Oh, S., Hennighausen, L., Tymoszuk, P., Doppler, W. et al. (2016). The BH3-only protein BIM contributes to late-stage involution in the mouse mammary gland. Cell Death Differ. 23, 41-51.

Shamas-Din, A., Brahmbhatt, H., Leber, B. and Andrews, D. W. (2011). BH3-only proteins: Orchestrators of apoptosis. Biochim. Biophys. Acta 1813, 508-520.

Shibata, M. A., Liu, M. L., Knudson, M. C., Shibata, E., Yoshidome, K., Bandey, T., Korsmeyer, S. J. and Green, J. E. (1999). Haploid loss of bax leads to accelerated mammary tumor development in C3(1)/SV40-TAg transgenic mice: reduction in protective apoptotic response at the preneoplastic stage. EMBO J. 18 2692-2701.

Souers, A. J., Leverson, J. D., Boghaert, E. R., Ackler, S. L., Catron, N. D., Chen J., Dayton, B. D., Ding, H., Enschede, S. H., Fairbrother, W. J. et al. (2013) ABT-199, a potent and selective BCL-2 inhibitor, achieves antitumor activity while sparing platelets. Nat. Med. 19, 202-208.

Stahl, M., Dijkers, P. F., Kops, G. J. P. L., Lens, S. M. A., Coffer, P. J., Burgering B. M. T. and Medema, R. H. (2002). The forkhead transcription factor FoxO 
regulates transcription of p27Kip1 and Bim in response to IL-2. J. Immunol 168, 5024-5031

Strange, R., Li, F., Saurer, S., Burkhardt, A. and Friis, R. R. (1992). Apoptotic cell death and tissue remodelling during mouse mammary gland involution. Development 115, 49-58.

Strange, R., Metcalfe, T., Thackray, L. and Dang, M. (2001). Apoptosis in norma and neoplastic mammary gland development. Microsc. Res. Tech. 52, 171-181.

Strasser, A., Cory, S. and Adams, J. M. (2011). Deciphering the rules of programmed cell death to improve therapy of cancer and other diseases. EMBO J. 30, 3667-3683

Su, G. H., Song, J. J., Repasky, E. A., Schutte, M. and Kern, S. E. (2002). Mutation rate of MAP2K4/MKK4 in breast carcinoma. Hum. Mutat. 19, 81.

Subramanian, R. R., Masters, S. C., Zhang, H. and Fu, H. (2001). Functiona conservation of 14-3-3 isoforms in inhibiting bad-induced apoptosis. Exp. Cell Res. 271, 142-151.

Thomas, S., Quinn, B. A., Das, S. K., Dash, R., Emdad, L., Dasgupta, S., Wang, X. Y., Dent, P., Reed, J. C., Pellecchia, M. et al. (2013). Targeting the Bcl-2 family for cancer therapy. Expert Opin Ther. Targets 17, 61-75

Tse, C., Shoemaker, A. R., Adickes, J., Anderson, M. G., Chen, J., Jin, S., Johnson, E. F., Marsh, K. C., Mitten, M. J., Nimmer, P. et al. (2008). ABT-263: a potent and orally bioavailable Bcl-2 family inhibitor. Cancer Res. 68, 3421-3428.

Tuzlak, S., Kaufmann, T. and Villunger, A. (2016). Interrogating the relevance of mitochondrial apoptosis for vertebrate development and postnatal tissue homeostasis. Genes Dev. 30, 2133-2151.

Tzung, S.-P., Kim, K. M., Basañez, G., Giedt, C. D., Simon, J., Zimmerberg, J., Zhang, K. Y. and Hockenbery, D. M. (2001). Antimycin A mimics a cell-deathinducing Bcl-2 homology domain 3. Nat. Cell Biol. 3, 183-191.

Vaillant, F., Merino, D., Lee, L., Breslin, K., Pal, B., Ritchie, M. E., Smyth, G. K., Christie, M., Phillipson, L. J., Burns, C. J. et al. (2013). Targeting BCL-2 with the BH3 mimetic ABT-199 in estrogen receptor-positive breast cancer. Cancer Cell 24, 120-129.

Vandenberg, C. J. and Cory, S. (2013). ABT-199, a new Bcl-2-specific BH3 mimetic, has in vivo efficacy against aggressive Myc-driven mouse lymphomas without provoking thrombocytopenia. Blood 121, 2285-2288.
Vaupel, P., Briest, S. and Hockel, M. (2002). Hypoxia in breast cancer: pathogenesis, characterization and biological/therapeutic implications. Wien. Med. Wochenschr. 152, 334-342.

Vogler, M., Dinsdale, D., Dyer, M. J. and Cohen, G. M. (2013). ABT-199 selectively inhibits BCL2 but not BCL2L1 and efficiently induces apoptosis of chronic lymphocytic leukaemic cells but not platelets. Br. J. Haematol. 163, 139-142.

Watson, C. J. (2006). Involution: apoptosis and tissue remodelling that convert the mammary gland from milk factory to a quiescent organ. Breast Cancer Res. 8 , 203

Wei, J., Kitada, S., Rega, M. F., Emdadi, A., Yuan, H., Cellitti, J., Stebbins, J. L., Zhai, D., Sun, J., Yang, L. et al. (2009). Apogossypol derivatives as antagonists of antiapoptotic Bcl-2 family proteins. Mol. Cancer Ther. 8, 904-913.

Whelan, K. A., Caldwell, S. A., Shahriari, K. S., Jackson, S. R., Franchetti, L. D., Johannes, G. J. and Reginato, M. J. (2010). Hypoxia suppression of Bim and Bmf blocks anoikis and luminal clearing during mammary morphogenesis. Mol. Biol. Cell 21, 3829-3837.

Wick, W., Petersen, I., Schmutzler, R. K., Wolfarth, B., Lenartz, D., Bierhoff, E. Hummerich, J., Muller, D. J., Stangl, A. P., Schramm, J. et al. (1996). Evidence for a novel tumor suppressor gene on chromosome 15 associated with progression to a metastatic stage in breast cancer. Oncogene 12, 973-978.

Wilson, W. H., O'connor, O. A., Czuczman, M. S., Lacasce, A. S., Gerecitano, J. F., Leonard, J. P., Tulpule, A., Dunleavy, K., Xiong, H., Chiu, Y. L. et al. (2010). Navitoclax, a targeted high-affinity inhibitor of BCL-2, in lymphoid malignancies: a phase 1 dose-escalation study of safety, pharmacokinetics, pharmacodynamics, and antitumour activity. Lancet Oncol. 11, 1149-1159.

Yang, J.-Y., Zong, C. S., Xia, W., Yamaguchi, H., Ding, Q., Xie, X., Lang, J.-Y., Lai, C.-C., Chang, C.-J., Huang, W. C. et al. (2008). ERK promotes tumorigenesis by inhibiting FOXO3a via MDM2-mediated degradation. Nat. Cell Biol. 10, 138-148. Youle, R. J. and Strasser, A. (2008). The BCL-2 protein family: opposing activities that mediate cell death. Nat. Rev. Mol. Cell Biol. 9, 47-59.

Zhong, Q., Gao, W., Du, F. and Wang, X. (2005). Mule/ARF-BP1, a BH3-only E3 ubiquitin ligase, catalyzes the polyubiquitination of $\mathrm{Mcl}-1$ and regulates apoptosis. Cell 121, 1085-1095. 